\title{
GAMBARAN KANDUNGAN ZAT GIZI PADA BERAS HITAM (Oryza sativa L.) KULTIVAR PARE AMBO SULAWESI SELATAN
}

\author{
${ }^{1}$ Juwita Mangiri \\ ${ }^{2}$ Nelly Mayulu \\ ${ }^{2}$ Shirley E. S. Kawengian
}

\author{
${ }^{1}$ Kandidat Skripsi Fakultas Kedokteran Universitas Sam Ratulangi Manado \\ ${ }^{2}$ Bagian Ilmu Gizi Fakultas Kedokteran Universitas Sam Ratulangi Manado \\ E-mail: juwitamangiri12127@gmail.com
}

\begin{abstract}
Rice is a staple food that is very important in the world, including in Indonesia. The kind of rice that is generally consumed by people in Indonesia is white rice, brown rice, and black rice. Black rice is one type of rice which is popular in the community and consumed as functional foods because of health benefits. The purpose of this study is to describe the nutrient contents of the black rice cultivars ambo Pare, South Sulawesi. This research was conducted by using descriptive method with samples of black rice originally from Toraja. The results of research which conducted at the Laboratory of Integrated Sam Ratulangi University and the Center for Environmental Health Engineering Manado are $85 \%$ carbohydrates, $1.9 \%$ fat, $1.04 \%$ protein, $10.5 \%$ water, fiber $0.8 \%$, Abu by $0.4 \%$, which amount of $0.6 \mathrm{mg}$ of Vitamin C, $31.6 \mathrm{mg}$ of Vitamin E, $0.386 \mathrm{mg} / \mathrm{ml}$ of Calcium (Ca), $1.95 \mathrm{mg} / \mathrm{ml}$ of Magnesium (Mg), $0.886 \mathrm{mg} / \mathrm{ml}$ of Potassium (K), 0,391mg / ml of iron (Fe), and $0.021 \mathrm{mg} / \mathrm{ml}$ of Zinc (Zn). The highest mineral content is Magnesium (Mg).
\end{abstract}

Keywords: Rice, Black Rice, Substance Nutrient Content

\begin{abstract}
Abstrak: Beras merupakan bahan makanan pokok yang sangat penting di dunia, termasuk di Indonesia. Beras yang umumnya dikonsumsi oleh masyarakat di Indonesia adalah beras putih, beras merah, dan beras hitam. Beras hitam merupakan salah satu jenis beras yang mulai populer di masyarakat dan dikonsumsi sebagai pangan fungsional karena bermanfaat bagi kesehatan. Tujuan penelitian ini adalah untuk mengetahui gambaran kandungan zat gizi pada beras hitam Kultivar pare ambo, Sulawesi Selatan. Penelitian ini dilakukan dengan menggunakan metode deskriptif dengan sampel beras hitam yang berasal dari Toraja. Berdasarkan hasil penelitian yang dilakukan di Laboratorium Terpadu Universitas Sam Ratulangi dan Balai Teknik Kesehatan Lingkungan Manado diperoleh hasil kandungan zat gizi antara lain Karbohidrat sebesar 85\%, Lemak sebesar 1,9\%, Protein sebesar 1,04\%, Air sebesar 10,5\%, Serat sebesar 0,8\%, Abu sebesar 0,4\%, Vitamin C sebesar 0,6 mg, Vitamin E sebesar 31,6 mg, Kalsium (Ca) sebesar 0,386 mg/ml, Magnesium (Mg) sebesar $1,95 \mathrm{mg} / \mathrm{ml}$, Kalium (K) sebesar 0,886 mg/ml, Besi (Fe) sebesar 0,391mg/ml, dan Zinc (Zn) sebesar $0,021 \mathrm{mg} / \mathrm{ml}$. Hasil dari kandungan mineral yang paling tinggi adalah Magnesium (Mg).
\end{abstract}

Kata Kunci: Beras, Beras Hitam, Kandungan Zat Gizi

Beras merupakan bahan makanan pokok yang sangat penting di dunia, termasuk di Indonesia. Indonesia adalah salah satu negara dengan konsumsi beras tertinggi di dunia, hal ini disebabkan oleh karena beras telah menjadi budaya yang tidak dapat dipisahkan dari penduduk Indonesia. ${ }^{1}$ Kebutuhan akan beras untuk memenuhi kebutuhan pangan 
selalu meningkat tiap tahunnya sejalan dengan pertambahan penduduk serta perubahan kebiasaan yang sebelumnya makanan utama bukan beras beralih ke beras. ${ }^{2}$

Beras yang umumnya dikonsumsi oleh masyarakat di Indonesia adalah beras putih, beras merah, dan beras hitam. Namun, beras yang paling banyak dikonsumsi adalah beras putih. Beras yang berwarna memiliki tekstur yang keras dibandingkan beras putih. Beras berwarna mempunyai pigmen atau zat warna yang termasuk dalam kelompok flavonoid yang disebut antosianin. Antosianin bersifat sebagai antioksidan yang berefek positif bagi kesehatan. ${ }^{3}$ Antioksidan merupakan senyawa yang mempunyai struktur molekul yang memberikan elektronnya secara cuma-cuma kepada mulekul radikal bebas tanpa terganggu fungsinya dan dapat memutus reaksi berantai radikal bebas. ${ }^{4}$

Beras hitam merupakan varietas lokal yang mengandung pigmen yang paling baik dibandingkan beras putih atau beras warna yang lain. Beras hitam merupakan salah satu jenis beras yang mulai populer di masyarakat dan dikonsumsi sebagai pangan fungsional karena bermanfaat bagi kesehatan. ${ }^{5}$

Sejumlah penelitian menunjukkan bahwa senyawa alami dalam makanan berperan penting dalam pencegahan berbagai penyakit kronis. Beberapa bukti menunjukkan bahwa antosianin sebagai antioksidan yang mempunyai efek protektif terhadap peradangan, aterosklerosis, karsinoma, dan diabetes. Antosianin merupakan pigmen alami yang termasuk golongan flavonoid yang bertanggung jawab terhadap warna merah, ungu, dan biru pada bahan makanan. Antosianin utama dalam beras hitam adalah cyanidin-3-glucoside (C3G) yang merupakan sumber antosianin penting di Asia. Selain itu, beras hitam mengandung fitokimia aktif seperti tokoferol, tokotrienol, oryzanols, vitamin B kompleks, dan senyawa fenolik. ${ }^{6}$

Khasiat yang dimiliki beras hitam lebih baik dibandingkan beras merah atau beras warna lain yaitu meningkatkan daya tahan tubuh, memperbaiki kerusakan sel hati, mencegah gangguan fungsi ginjal, mencegah kanker atau tumor, memperlambat penuaan, sebagai antioksidan, membersihkan kolestrol dalam darah, dan mencegah anemia. ${ }^{5}$ Penelitian ini bertujuan untuk menentukan kandungan zat gizi pada beras hitam (Oryza sativa L.) kultivar pare ambo Sulawesi Selatan.

\section{METODOLOGI PENELITIAN}

Penelitian ini merupakan penelitian yang bersifat deskriptif. Penelitian ini dilakukan di Laboratorium Terpadu Universitas Sam Ratulangi dan Balai Teknik Kesehatan Lingkungan Manado dengan objek penelitian adalah beras hitam kultivar pare ambo Sulawesi Selatan.

\section{HASIL PENELITIAN}

Berdasarkan penelitian yang bersifat deskriptif untuk mengetahui gambaran kandungan zat gizi pada beras hitam kultivar Toraja Sulawesi Selatan, didapatkan hasil pemeriksaan kandungan zat gizi dari Laboratorium Terpadu Universitas Sam Ratulangi dan Balai Teknik Kesehatan Lingkungan Manado memberikan hasil sebagai berikut:

Tabel 2. Hasil Uji Zat Gizi Beras Hitam Toraja

\begin{tabular}{lc}
\hline Variabel & Hasil (\%) \\
\hline Karbohidrat & 85 \\
Lemak & 1,9 \\
Protein & 1,04 \\
Air & 10,5 \\
Serat & 0,8 \\
Abu & 0,4 \\
\hline
\end{tabular}

Berdasarkan tabel 2 diperoleh hasil Karbohidrat sebesar 85\%, Lemak sebesar $1,9 \%$, Protein sebesar 1,04\%, Air sebesar $10,5 \%$, Serat sebesar 0,8\%, dan Abu sebesar 
$0,4 \%$.

Tabel 3. Hasil Uji Vitamin Beras Hitam Toraja

\begin{tabular}{ll}
\hline Variabel & Hasil $(\mathrm{mg})$ \\
\hline Vitamin C & 0,6 \\
Vitamin E & 31,6 \\
\hline
\end{tabular}

Berdasarkan tabel 3 diperoleh hasil uji vitamin C sebesar 0,6 mg, dan vitamin $\mathrm{E}$ sebesar 31,6 mg.

Tabel 4. Hasil Uji Mineral Beras Hitam Toraja

\begin{tabular}{ll}
\hline Variabel & Hasil $(\mathrm{mg} / \mathrm{ml})$ \\
\hline Kalsium (Ca) & 0,368 \\
Magnesium (Mg) & 1,95 \\
Kalium (K) & 0,886 \\
Besi (Fe) & 0,391 \\
Zinc (Zn) & 0,021 \\
\hline
\end{tabular}

Berdasarkan tabel 4 diperoleh hasil Kalsium (Ca) 0.368 mg/ml, Besi (Fe) 0.391 $\mathrm{mg} / \mathrm{ml}$, Kalium (K) 0.886 mg/ml, Magnesium (Mg) $1.95 \mathrm{mg} / \mathrm{ml}$, Zinc (Zn) $0.021 \mathrm{mg} / \mathrm{ml}$. Hasil dari kandungan mineral yang paling tinggi adalah variabel Magnesium (Mg).

\section{BAHASAN}

Beras tidak hanya berfungsi sebagai bahan makanan pokok tetapi juga berfungsi sebagai bahan pangan fungsional yang memiliki komponen aktif yang berguna bagi kesehatan. Jenis beras yang dapat digunakan sebagai bahan pangan fungsional adalah beras hitam. Jenis beras ini selain mengandung karbohidrat, lemak, protein, serat dan mineral juga mengandung antosianin dan banyak dikonsumsi sebagai makanan sehat di China dan negara Asia Timur lainnya. ${ }^{7}$

Dari hasil penelitian kandungan zat gizi pada beras hitam kultivar Toraja Sulawesi Selatan, pada Bulan November-Desember 2015 diperoleh hasil karbohidrat sebesar 85\%.
Penelitian yang dilakukan oleh Nani Ratnaningsih dkk (2010) ${ }^{8}$ diperoleh hasil karbohidrat sebesar 72,49 - 83,94\%. Karbohidrat merupakan salah zat gizi yang berfungsi untuk menghasilkan energi bagi tubuh manusia. Selain itu, karbohidrat juga berfungsi sebagai pemberi rasa manis pada makanan, penghemat protein, pengatur metabolism lemak, membantu pengeluaran feses. ${ }^{9}$

Kandungan lemak beras hitam Toraja diperoleh hasil sebesar 1,9\%. Penelitian yang dilakukan oleh Nani Ratnaningsih dkk $(2010)^{8}$ diperoleh hasil lemak sebesar 2,33 2,88\%. Lemak merupakan zat makanan yang penting untuk menjaga kesehatan tubuh manusia. ${ }^{10}$ Lemak berfungsi sebagi sumber energi, melarutkan vitamin sehingga dapat diserap oleh usus, dan memperlama rasa kenyang. ${ }^{11}$

Kandungan protein beras hitam Toraja diperoleh hasil sebesar 1,04\%. Penelitian yang dilakukan oleh Nani Ratnaningsih dkk $(2010)^{8}$ diperoleh hasil protein sebesar 8,40 10,44\%. Protein merupakan bahan utama pembentuk sel tumbuhan, hewan dan manusia. Kurang lebih $3 / 4$ zat padat tubuh adalah protein. Protein berfungsi sebagai pertumbuhan dan pemeliharaan, pembentukan ikatan-ikatan esensial tubuh, mengatur keseimbangan air, memelihara netralitas tubuh, pembentukan antibodi, mengangkut zat-zat gizi, dan sumber energi. ${ }^{11}$

Kandungan air beras hitam Toraja diperoleh hasil sebesar 10,5\%. Air merupakan komponen terbesar dalam struktur tubuh manusia. Air berfungsi sebagai media transfortasi zat-zat gizi, membuang sisa-sisa metabolisme, mengatur temperatur tubuh selama aktivitas fisik, dan mempertahankan keseimbangan volume darah. ${ }^{11}$

Kandungan serat beras hitam Toraja diperoleh hasil sebesar 0,8\%. Penelitian yang dilakukan oleh Nani Ratnaningsih dkk $(2010)^{8}$ diperoleh hasil serat sebesar 1,09 $1,28 \%$. 
Kandungan abu beras hitam Toraja diperoleh hasil sebesar 0,4\%. Penelitian yang dilakukan oleh Nani Ratnaningsih dkk $(2010)^{8}$ diperoleh hasil abu sebesar 0,71 1,69\%. Kadar abu merupakan residu yang diperoleh setelah beras mengalami oksidasi karena panas, kadar abu sebagai ukuran kandungan mineral dalam beras. ${ }^{12}$

Kandungan vitamin $\mathrm{C}$ beras hitam Toraja diperoleh hasil sebesar 0,6 mg. Vitamin C adalah antioksidan poten yang banyak terdapat pada buah-buahan dan sayuran seperti jeruk, papaya, dan brokoli. Vitamin C juga ditemukan pada beberapa serealia seperti beras merah dan beras hitam. ${ }^{13}$ Vitamin C meningkatkan fungsi imun dengan menstimulasi produksi interferon (protein yang melindungi sel dari serangan virus). Vitamin C juga mempunyai peran dalam sintesa kolagen untuk menjaga kesehatan kulit. $^{14}$

Kandungan vitamin E beras hitam Toraja diperoleh hasil sebesar 31,6 mg. Vitamin E atau $\alpha$-tokoferol merupakan vitamin larut lemak. Vitamin ini banyak terdapat dalam membran eritrosit dan lipoprotein plasma. Tokoferol terutama $\alpha$-tokoferol telah diketahui sebagai antioksidan yang mampu mempertahankan integritas membrane sel. Peran besar vitamin E sebagai antioksidan lebih disebabkan karena vitamin $\mathrm{E}$ mempunyai cincin fenol yang mampu memberikan ion hidrogennya kepada radikal bebas. ${ }^{14}$

Kandungan mineral pada beras hitam Toraja berupa kalsium (Ca) sebesar 0,368 $\mathrm{mg} / \mathrm{ml}$, magnesium (Mg) sebesar 1,95 mg/ml, kalium (K) sebesar 0,886 $\mathrm{mg} / \mathrm{ml}$, besi (Fe) sebesar 0,391 $\mathrm{mg} / \mathrm{ml}$, dan zinc (Zn) sebesar $0,021 \mathrm{mg} / \mathrm{ml}$. Penelitian yang dilakukan oleh Nani Ratnaningsih dkk (2010) ${ }^{8}$ diperoleh hasil besi (Fe) sebesar 5,64 - 8,07. Mineral adalah zat organik yang diperlukan oleh tubuh dalam jumlah kecil untuk membantu reaksi fungsional tubuh, misalnya untuk memelihara keteraturan metabolisme. Kurang lebih 4\% berat tubuh manusia terdiri atas mineral. ${ }^{11}$ Kalsium (Ca) merupakan makromineral esensial dalam tubuh. Fungsi kalsium adalah sebagai penyusun struktur rangka/tulang dan berperan dalam metabolisme tubuh. ${ }^{20}$ Besi (Fe) sangat berperan dalam sintesa hemoglobin dan terkait erat dengan masalah anemia. $^{14}$ Zinc (Zn) memegang peranan penting dalam banyak fungsi tubuh. Zinc berperan dalam proliferasi sel terutama sel mukosa. $^{14}$

\section{SIMPULAN}

Berdasarkan hasil penelitian yang dilakukan di Laboratorium Terpadu Universitas Sam Ratulangi dan Balai Teknik Kesehatan Lingkungan dapat disimpulkan bahwa terdapat kandungan zat gizi makro beras hitam Toraja yaitu karbohidrat sebesar $85 \%$, lemak sebesar 1,9\%, protein sebesar $1,04 \%$, air sebesar 10,5\%. Kandungan serat beras hitam Toraja sebesar 0,8\%.Kandungan mineral beras hitam Toraja yang terdiri dari kalsium (Ca) sebesar 0,386 $\mathrm{mg} / \mathrm{ml}$, magnesium (Mg) sebesar 1,95 mg/ml, kalium (K) sebesar 0,886 $\mathrm{mg} / \mathrm{ml}$, besi (Fe) sebesar 0,391mg/ml, dan zinc (Zn) sebesar 0,021 $\mathrm{mg} / \mathrm{ml}$. Kandungan vitamin $\mathrm{C}$ dan vitamin $\mathrm{E}$ sebesar 0,6 mg dan 31,6 mg.

\section{SARAN}

1. Beras hitam mengandung nilai gizi yang tinggi dan berdampak positif bagi kesehatan untuk itu perlu adanya sosialisasi mengenai beras hitam kepada masyarakat

2. Bagi peneliti selanjutnya agar meneliti kandungan zat gizi lain pada beras hitam Toraja yang belum diteliti

3. Diperlukan penelitian lebih lanjut mengenai kandungan zat gizi pada beras hitam di daerah lain

\section{DAFTAR PUSTAKA}

\section{Monika P, Saputrajaya W, Ligouri C,Widyawati PS, Suteja AM,}


Indarto $\mathbf{T}$, et al. Aktivitas antioksidan beras organik varietas lokal (putih varietas Cianjur, merah varietas Saodah, hitam varietas Jawa). Seminar Nasionional. 2013:791-99.

2. Sa'adah IR, Supriyanta, Subejo.

Keragaman warna gabah dan warna beras varietas lokal padi beras hitam (Oryza sativa L.) yang dibudidayakan oleh petani kabupaten Sleman, Bantul, dan Magelang. Vegetalika. 2013;2:13-20.

3. Sutharut J, Sudarat J, Total anthocyanin content and antioxidant activity of germinated colored rice. International Food Research Journal. 2012:215-21.

4. Maulida R, Guntarti A. Pengaruh ukuran partikel beras hitam (Oryza sativa L.) terhadap rendemen ekstrak dan kandungan total antosianin. Pharmaciana. 2015;5:9-16.

5. Beras hitam, pangan berkhasiat yang belum popular. Warta Penelitian dan Pengembangan Pertanian. 2009;31:910. [cited 2015 Oct 03]. Available from:

http://pustaka.litbang.pertanian.go.id/ publikasi/wr312095.pdf

6. Jang HH, Park MY, Kim HW, Lee YM, Hwang KA, Park JH, et al. Black rice (Oryza sativa L.) extract attenuates hepatic steatosis in C57BL/6 J mice fide a high-fat diet via fatty acid oxidation. Nutrition and Metabolism. 2012;2-11.
7. Kisbintari W, Purwanto E, Mursito D. Effect of Drought Stresses On Growth and Anthocyanin Content of Black Rice and Brown Rice. Journal of Agronomy Research. 2013:47-52.

8. Ratnaningsih $\mathbf{N}$, Ekawatiningsih $\mathbf{P}$. Potensi Beras Hitam Sebagai Sumber Antosianin dan Aplikasinya pada Makanan Tradisional Yogyakarta. Bidang MIPA dan Sains. 2010:173174.

9. Siregar SN. Karbohidrat. Jurnal Ilmu Keolahragaan. 2014;13:38-44.

10. Hermanto S, Muawanah A, Wardhani P. Analisis Tingkat Kerusakan Lemak Nabati dan Lemak Hewani Akibat Proses Pemanasan. 2011:33.

11. Surbakti S. Asupan Bahan Makanan dan Gizi Bagi Atlet Renang. Jurnal Ilmu Keolahragaan. 2010;8:110.

12. Widyawati SP, Suseno PIT, Sutedja MA. Perbedaan Sifat Fisikokimia, Sensori dan Aktivitas Antioksidan Beras Organik Lokal. Prosiding Seminar INSINAS. 2013:111.

13. Moertolo YS. Pemberian krim ekstrak beras hitam (Oryza sativa L. indica) menghambat penurunan jumlah kolagen pada tikus (Rattus norvegicus) galur wistar yang dipapar sinar ultra violet-B [tesis]. Universitas Udayana Denpasar; 2015.

14. Siswanto, Budisetyawati, Ernawati F. Peran Beberapa Zat Gizi Mikro Dalam Sistem Imunitas. Gizi Indon. 2013;36:57-64. 